\title{
How to Succeed in the Presence of Financial and Technological Gaps: \\ From the Perspective of Governance Innovation*
}

\section{HANNAH JUN ${ }^{* *} \cdot$ WONSEOK WOO ${ }^{* * *}$ AND HYOUNG-GOO KANG ${ }^{* * * *}$}

Conventional wisdom would predict firms with little financial and technological capabilities to fail. This is especially true for such firms in the high-tech sector during periods of industry downturn. In this paper, we ask how firms experiencing financial and technological gaps can succeed by transforming current challenges into opportunities via governance innovation. We select Hynix and the semiconductor industry for the investigation. Hynix emerged from near bankruptcy become the number two player in the global semiconductor memory market. We find that Hynix's case requires extending prevailing theory to focus on governance and control. We pinpoint specific factors that contributed to Hynix's success from the perspective of governance innovation for the theoretical extension and suggest practical implications.

Keywords: Control, Dynamic Capabilities, Governance Innovation, Hynix, Management Innovation

* This research is supported by the Ewha Global Top 5 Research Fund (No. 1-2011-1686-001-3).

** Assistant Professor, Hankuk University of Foreign Studies; E-mail: hannahjun@hufs.ac.kr

*** Associate Professor, Ewha Womans University; E-mail: wwoo@ewha.ac.kr

**** Assistant Professor, Hanyang University; E-mail: hyoungkang@hanyang.ac.kr 


\section{INTRODUCTION}

The question of how firms can achieve long-term success continues to spur academic thinking and debate. Particularly with regard to relatively new firms or ventures in the high-tech sector, previous studies have explored this question with special focus on founding teams, top management performance, strategy, technological edge, and competitive landscape (e.g., Cooper and Bruno 1977; Eisenhardt and Schoonhoven 1990; Feeser and Willard 1989; Haleblian and Finkelstein 1993; Roberts 1992; Roure and Keeley 1990). Findings have been helpful in suggesting several specific factors or qualities of a firm which can collectively increase the firm's likelihood of success. But while this area of research is useful in highlighting potential predictors of success for relatively new firms or ventures, it has weaker prescriptive power in addressing how established "have-not" firms - especially for those in volatile industries such as the high-tech sector - can make the leap from failure to success. For example, findings on the role of founding teams in contributing to success may have greater value for companies in the start-up phase, but may prove less significant for firms that are already in operation and have no means to change founding conditions.

In response, there have been a growing number of studies on innovation and increasing the innovative capabilities of a firm in driving firm success. As summarized by Birkinshaw et al. (2008), major areas of research include technological innovation, process innovation, service innovation, strategic innovation, and management innovation. In seeking to answer our question of how established firms with limited capabilities make the transition from failure to success, we examined the definition found in Birkinshaw et al. (2008) of "management innovation," namely, "the invention and implementation of a management practice, process, structure, or technique that is new to the state of the art and is intended to further organizational goals." Upon a detailed analysis of Hynix Semiconductor Inc. (hereafter referred to as "Hynix") and the semiconductor memory industry, we propose an extension of existing theory by examining more closely the innovation process as it relates to control structures of a firm and strategic decision-making, or what we term governance innovation.

Through our analysis, we explore what conditions allowed for innovation to take place and, in the process, create a tangible framework as an extension to existing theory. We argue that governance innovation was central to Hynix's success as it created the system whereby agents of change had free reign to direct strategy, mobilize labor, and improve efficiency. Furthermore, we believe the role of governance innovation was even more important as the firm lacked typically "ideal" capabilities.

We also propose several practical implications through our study. First, our prescriptive framework can be used by firms looking to replicate Hynix's success, 
particularly if they experience financial and technological gaps vis-à-vis peers. Second, investors in capital markets can find long-term investment opportunities in firms with potential for governance innovation, but are currently underpriced due to financial and technological challenges. Third, market leaders can prepare for possible challenges from currently-depressed competitors who have the potential for governance innovation. For our study, we broadly follow Eisenhardt's framework in building theories from case study research (1989).

\section{DATA AND METHODS}

For our investigation, we chose Hynix and the semiconductor memory industry between 1999 and 2007. In considering our target industry, availability and measurability of data were key factors. Given the dynamic nature of the memory industry, a firm's success can be gauged simply by tracking whether it remained in business over the course of a specific period of time. Additionally, available quantitative measures of success include market share and profit margin trends, as well as qualitative measures such as employee morale and external perception (e.g., media).

Within the memory industry, we selected Hynix for our in-depth analysis. Compared to the amount of media attention highlighting Hynix's success, as well as its reputation in the domestic market and investment community, there is a surprising lack of academic research on the firm and factors that contributed to its success. This is even more so the case as it emerged from near bankruptcy and a weak productivity base to become the current number two player in the global semiconductor memory market. Taken together with access to timely quantitative and qualitative data, Hynix was the ideal choice for our investigation.

In rationalizing why we selected Hynix for our study, we further offer reasons why Hynix was our only choice. For one, as noted by Pettigrew (1988), it makes sense to choose cases such as extreme situations (in this case, Hynix) in which the process of interest is "transparently observable." We view Hynix to be the most extreme success case in recent years given its unique and dynamic history, which includes: struggling to realize synergies and amassing a huge debt burden after Hyundai Electronics and LG Semicon merged in 1999; coming close to bankruptcy and being bailed out by the government; evading a takeover attempt by rival Micron Technology in 2002; and successfully turning its business around to become one of the industry's top players. And as our study relates to control structures and management initiatives, the processes were also transparently observable via company data as well as media reports. Additionally, given the firm's colorful history, an in-depth study solely on Hynix also made practical sense considering the sheer amount of data available. But while Hynix remains the core example used for the theoretical extension, we juxtapose the firm's history and characteristics with brief analyses of relevant industry players as well. 


\section{Crafting Instruments and Protocols}

Semi-structured interviews with senior management and industry experts formed the primary source of qualitative data for our study. Subjects were active in the firm or industry over the period of our analysis (i.e., 1999 to 2007) and had close working relationships or first-hand experience with key members of the firm and/or government. For firm employees, we interviewed the current CEO, whose previous capacities included strategy, planning, and investor relations. Questions prepared for interviews were standardized, while some flexibility in questions was allowed for clarification and supplemental purposes.

\section{TABLE 1. SUMmary OF Key EVEnTS}

\begin{tabular}{|c|c|c|}
\hline Description & $\begin{array}{l}\text { M\&A Complications } \\
(1999-)\end{array}$ & $\begin{array}{c}\text { Industry Downturn and } \\
\text { Acquisition Attempt (2000-2002) }\end{array}$ \\
\hline $\begin{array}{l}\text { Sources of } \\
\text { Internal } \\
\text { Crisis }\end{array}$ & $\begin{array}{l}* \text { huge post-merger debt ( } 15.8 \text { trillion won } \\
\text { at end-1999) } \\
* \text { difficulty realizing post-M\&A synergies } \\
\text { between two companies, need to } \\
\text { streamline businesses } \\
* \text { poor internal controls }\end{array}$ & $\begin{array}{l}\text { * legacy liabilities weighing on } \\
\text { company } \\
\text { * falling profitability of operations } \\
\text { * takeover bid attempt by Micron } \\
\text { (2002) }\end{array}$ \\
\hline $\begin{array}{l}\text { Sources of } \\
\text { External } \\
\text { Crisis }\end{array}$ & $\begin{array}{l}\text { * control struggle between internal } \\
\text { management and government, creditor } \\
\text { banks }\end{array}$ & $\begin{array}{l}\text { * unprecedented DRAM industry } \\
\text { downturn } \\
\text { * issue of countervailing duties and } \\
\text { complaints by US, Europe, Japan }\end{array}$ \\
\hline
\end{tabular}

\section{TABle 2. TIMELINE OF Key EVEnTS PRIOR TO TURNAROUND}

\begin{tabular}{cl}
\hline Year & \multicolumn{1}{c}{ Key Events and Description } \\
\hline 1983 & Hyundai Electronics Industries Co., Ltd. founded (predecessor to Hynix Semiconductor) \\
\hline 1986 & Completion of semiconductor fabrication plant (“fab") in Icheon, Korea \\
\hline 1990 & Large-scale investment by Hyundai Electronics in response to industry upturn \\
\hline $1997-8$ & $\begin{array}{l}\text { Asian financial crisis led to restructuring of conglomerates; "Big Deals" consisting of } \\
\text { swaps and mergers in key industries for the five largest conglomerates began taking place }\end{array}$ \\
\hline 1999 & $\begin{array}{l}\text { Merger between Hyundai Electronics and LG Semicon (number two and three players in } \\
\text { the local semiconductor market) into "Hynix"; debt reached 15.8 trillion won }\end{array}$ \\
\hline 2001 & Unprecedented industry downturn in global memory industry \\
\hline 2001 & August: Hynix spun-off from Hyundai Group as standalone company \\
\hline 2001 & October: Hynix placed under Corporate Restructuring Promotion Act \\
\hline 2001 & $\begin{array}{l}\text { November: Hynix undergoes second phase of comprehensive debt restructuring, including } \\
\text { 3.0 trillion won debt-to-convertible bond swap, 1.4 trillion won in debt write-downs, 3.2 } \\
\text { trillion won of extensions of mature debt and refinancing }\end{array}$ \\
\hline 2002 & $\begin{array}{l}\text { Acquisition proposal by Micron Technology, Inc. of \$3.4 billion; rejected by board of } \\
\text { directors }\end{array}$ \\
\hline 2003 & $\begin{array}{l}\text { In light of allegations of unfair government subsidies, US and European Union place } \\
\text { countervailing duties on imports of Hynix's DRAM chips manufactured in Korea at rates of } \\
58 \% \text { and 35\%; Japan places duties of 27\% for Hynix’s DRAM chips manufactured in Korea }\end{array}$ \\
\hline
\end{tabular}


Quantitative data used to enhance our findings include company financial data and industry data sources including Bloomberg, Gartner Dataquest, iSuppli, and Worldwide Semiconductor Trade Statistics (WSTS). Quantitative data were used to track share price performance, market share as well as profit margin trends.

The following provides a summary of the narrative of key phases in Hynix's recent history (1999-2007), based on findings from this study as well as those by Jun et al. (2013).

\section{DATA ANALYSIS}

On the one hand, we acknowledge that many important influences on Hynix's recent history were uncontrollable, environmental factors which undoubtedly contributed to the firm's survival. Of these, we highlight favorable industry dynamics and foreign exchange as key elements. In addition, many industry watchers have specifically pointed to the string of government initiatives and bailout schemes as the key to Hynix's turnaround. But while we acknowledge that these factors created a more favorable environment versus that which was present during Hynix's crisis years, we believe they are insufficient in explaining the level of success the firm achieved so soon after its near-collapse. For one, even during the industry upturn, we saw clear profit differentiation between Hynix and other memory manufacturers, notably Micron. This is clearer when comparing share prices trends over the period of our study. As such, this explanation is insufficient in showing that favorable industry dynamics alone contributed to Hynix's outper-formance. Also, while the government bailout may have been a necessary condition for the firm's immediate survival, we view that the bailout itself is insufficient in explaining the level of success seen by the company specifically because the bailout was separate to the generation and execution of key strategic and technological initiatives were taken by the firm. In fact, we note that the government and creditor banks initially opposed some strategic alliances proposed by management-alliances which ultimately proved successful. Thus in the analysis of our data, we focus on the internal changes that took place at the firm, specifically regarding changes in control and governance mechanisms, which drove the company's turnaround.

In our analysis, we: (1) examine what innovations in control and governance took place during the major phases in Hynix's recent history; and (2) highlight how such innovations permitted agents within the organization to drive initiatives aimed at improving performance. To this end, we first define dependent and independent variables as follows.

\section{Dependent Variables}

Dependent variables in our study are quantitative measures of firm performance as gathered over the course of our investigation. We chose market share, 


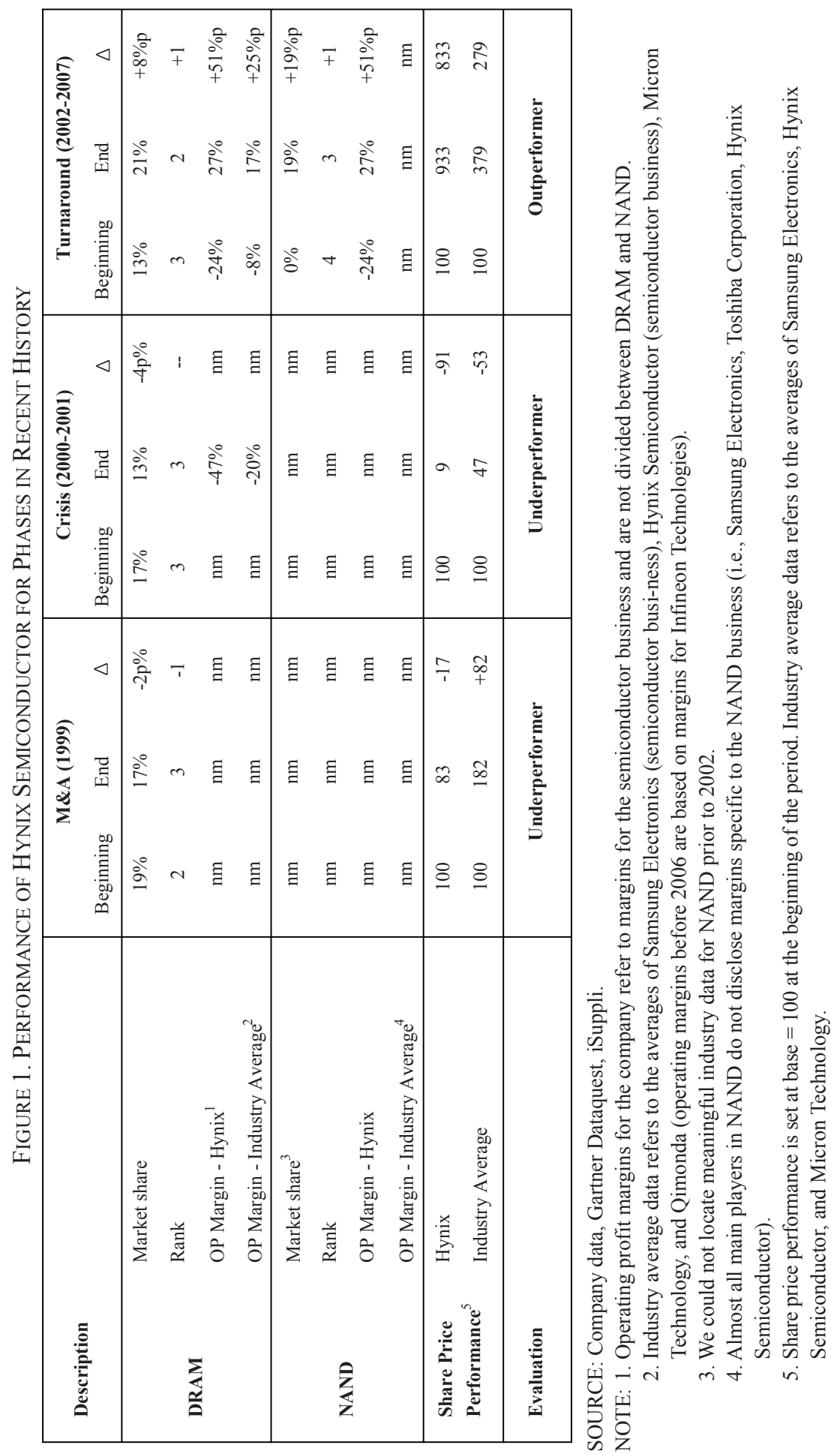


operating profit margins, and share price performance. Market share is based on revenue, with data collected from Gartner Dataquest, iSuppli, and company data. Operating profit margins refer to margins for the overall memory business, as margins for DRAM and NAND flash are typically not revealed separately. Margin data is based on company data. Share price performance is based on raw data collected from Bloomberg. Market share, margins, and share price performance are analyzed for each of the three phases in Hynix's recent history: (1) M\&A; (2) crisis; and (3) turnaround. In addition to comparing absolute measures of performance for the firm itself, we provide a relative comparison using respective data for key competitors as well as industry data (where available) to get a sense of Hynix's performance versus peers. Our goals in doing so specifically include: (1) highlighting Hynix's outperformance; and (2) isolating factors for its outperformmance separate to environmental aspects, which arguably affected all industry players.

For each phase, we gauge Hynix's performance relative to its peers and consequently label the firm an underperformer, market performer, or outperformer. Based on a summary of our findings in Figure 1, we conclude the following for each of the three phases:

i. M\&A phase: underperformer

ii. Crisis phase: underperformer

iii. Turnaround phase: outperformer

Over the M\&A phase, Hynix's DRAM market share fell from 19\% at the beginning of the period to $17 \%$, with its ranking falling from number two to number three. Even more telling was its share price performance versus peers, as Hynix's share price fell $17 \%$ over the course of the year while average industry share prices increased $82 \%$ over the same period. During the crisis phase, although the firm maintained its global ranking, market share continued to slip from $17 \%$ to $13 \%$ by end-2001. Although the downturn negatively affected share price performance for all industry players (down 53\% between beginning-2000 and end-2001), Hynix's share price fell even further. Thus for both phases, we concluded that Hynix underperformed the industry based on most of our measures.

Going into the turnaround phase, we see a distinct improvement in market share, ranking, as well as operating margins. DRAM market share for the firm rose $8 \%$ ppts from $13 \%$ to $21 \%$, while its ranking rose from number three to number two. NAND market share also jumped from close to $0 \%$ to $19 \%$ over the same period, with its number four rank improving one notch. Although DRAM operating profit margins improved for both the industry and the firm, operating margins for the industry rose $25 \%$ ppts over the period while Hynix's increased by $51 \%$ ppts. Even if we assume that NAND flash generated higher margins than those for 
DRAM, we believe the level of improvement differentiates Hynix's performance versus that of its peers. And while the market upturn resulted in a near three-fold increase in average share prices between 2002 and 2007, Hynix's share price surged over eight-fold. Based on the above data, we evaluate Hynix to have been an outperformer.

\section{Independent Variables}

We measure the level of governance innovation in the firm qualitatively. For the purposes of our study, we define governance innovation as a new structure that generates and cultivates innovation in the organization's control mechanisms with the goal of fostering innovative processes. We note that innovation of control mechanisms can include cooperative competition, or "co-opetition", as seen in our case study, while innovative processes can include strategic initiatives, technological innovations, and innovations in productivity and efficiency improvement (Brandenburger and Nalebuff 1997).

In measuring levels of governance innovation, interviews with management, industry experts, and company materials are used to form the base of our analysis. For each phase, we label the level of governance innovation as "high" or "low." High levels of governance innovation are first characterized by the presence of innovation of control mechanisms within the firm as well as the development and execution of new innovative processes, while low levels are characterized by the opposite.

\section{FIGURE 2. COORDINATION AND CONTROL SPACE} Formalization

High

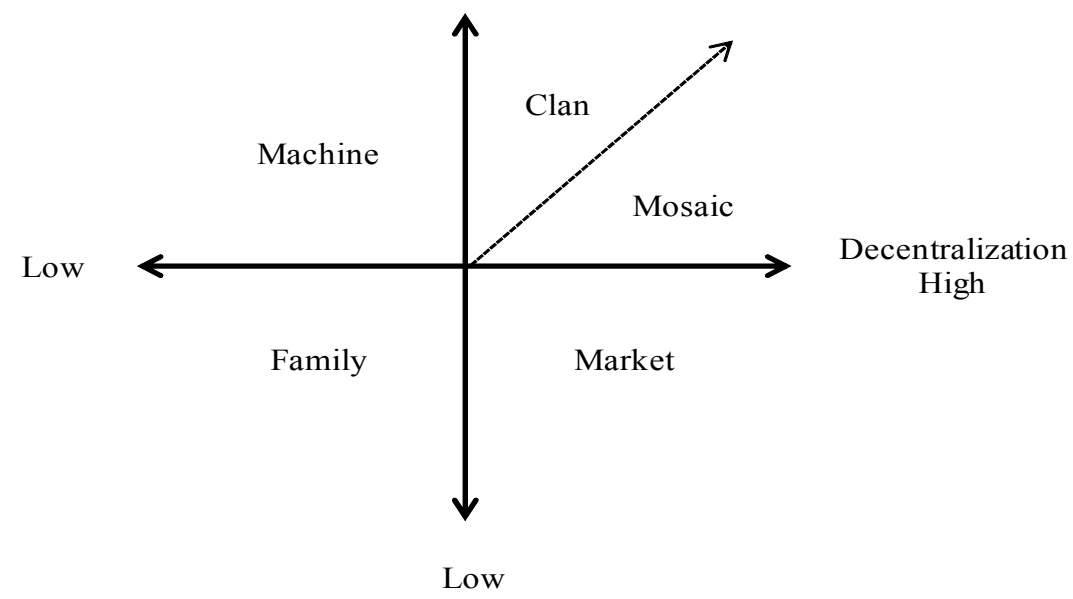

SOURCE: Burton et al. (2006). 
As a prior construct to our analysis, we also categorize the control systems of the firm for each phase based on Burton et al. (2006) classifications. Depending on the degree of formalization and centralization, firms fall within five major designs: (1) family (low formalization, low decentralization); (2) machine (high formalization, high centralization); (3) market (low formalization, high decentralization); (4) clan (high formalization, high decentralization); and (5) mosaic (high formalization, high decentralization) (Figure 2). The clan model tends toward somewhat greater formalization and less decentralization, while the mosaic model tends toward somewhat less formalization and greater decentralization versus the clan model (Burton et al. 2006). Under this construct, formalization refers to the degree to which the firm specifies a set of rules or codes to govern how work is done, and centralization refers to the degree to which coordination and control are managed by a core person or level in the organization.

In classifying each period according to the type of control model and the level of governance innovation, we summarize our findings in Figure 3 and conclude the following:

\section{i. M\&A phase: market/low \\ ii. Crisis phase: market/low \\ iii. Turnaround phase: machine/high}

For the M\&A and crisis phases, evidence supported the observation that formalization at the firm was low. Variations in control and coordination which typify low formalization were due to initial difficulties following the merger and delays in streamlining businesses, with both factors contributing to inconsistency in control and coordination. We also note that Hynix's CEO mentioned a "lack of transparency" as a key company-specific issue.

At the same time, decentralization of control was high during both phases. Given the disorder following the merger and the industry downturn that soon followed, it was difficult to know who was in charge. During that short time, many players had exercised tremendous power: the government first initiated the merger; former Hyundai employees were given initial reign over the newlymerged firm; creditor banks became involved as part of the government bailout scheme; and government and creditor banks supported the Micron takeover bid while the BOD and employees did not. Unsurprisingly, the CEO and key managers cited that these years were marked by "poor internal controls."

Given low formalization and high decentralization, we categorize both phases as exhibiting a market-style control design. While the market design may be viewed as providing a firm flexibility and more easily allowing for innovation, we believe internal and external crises during this period may have further inhibited the company from taking strategic and necessary action. Our analysis leads us to conclude that the M\&A and crisis periods exhibited low levels of governance innovation. 


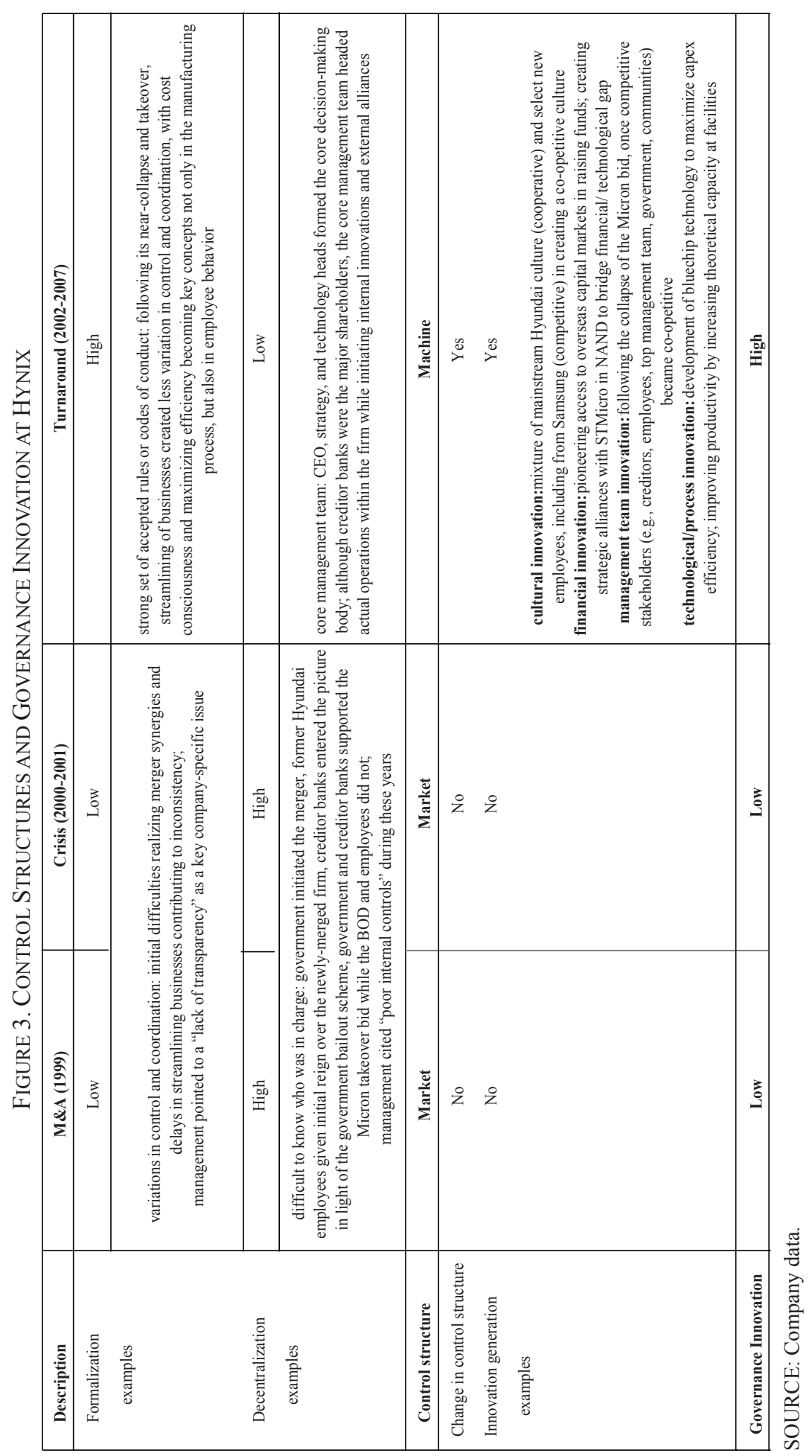


The unsuitability of the market design along with the failure of the takeover bid by Micron contributed to an upheaval in the control mechanisms of the firm. Now firmly under the Hynix banner, we saw the emergence of a strong set of accepted rules or codes of conduct. The streamlining of businesses created less variation in control and coordination, and cost consciousness and efficiency maximization became key tenets for both the manufacturing process and employee behavior.

Also during this time, strategic decision-making became centralized under a core management team, which included the CEO and the heads of strategy and technology. Although creditor banks were the major shareholders, the core management team headed actual operations within the firm while initiating internal innovations and external alliances.

With the transition to a machine design of high formalization and low decentralization, we saw the generation and execution of many important innovations that led to the firm's success and outperformance. These include: (1) cultural innovation; (2) financial innovation; (3) management team innovation; and (4) technology and process innovation.

\section{Analysis Summary}

In isolating the level of governance innovation at Hynix and the generation of innovative processes as a result, we argue that higher governance innovation at the beginning of the firm's turnaround phase was the trigger to its outperformance. This is because the resulting control mechanism enabled the firm to successfully streamline its business, focus on improving technology and reducing costs, enter growing markets within the semiconductor memory industry, and effectively mobilize labor. Combined with an effective strategy, we believe the firm was able to turn its business around despite having faced financial and technological gaps.

\section{SHAPING HYPOTHESES}

While acknowledging favorable external conditions such as an industry upturn and a weaker Korean won, our analysis suggests that governance innovation at the early stage of Hynix's turnaround served as the catalyst for the firm's outper-formance through to 2007. Thus based on our findings, we offer several propositions.

First, when analyzing the three phases of Hynix's recent history, both the $M \& A$ and crisis periods were marked by clear underperformance relative to peers, with performance worsening as the company transitioned from the M\&A period into the crisis years. Control structures were characterized by low formalization and high decentralization, with little to no generation or cultivation of innovation in control mechanisms. 
Conversely, the turnaround phase began with dramatic changes in control structures, with mechanisms characterized by a high degree of formalization and low decentralization. Through successful governance innovation, a culture was created whereby the generation and execution of many innovative initiatives were encouraged-initiatives which in turn led to the firm's outperformance versus peers. Thus given this observation, we propose the following:

Proposition 1: The higher the governance innovation, the more successful a firm can become.

Particularly when producing commodity goods, maintaining a favorable cost structure vis-à-vis peers becomes crucial to surviving and staying ahead. For companies that do not have an abundance of financial resources, the ability to maximize efficiency of capital through financial and technological innovation becomes even more important. Our case study suggests that governance innovation was necessary in unlocking other forms of innovation to take place. As such, we propose:

Proposition 2: The lower the financial resources a firm has, the more important the role of governance innovation in making the firm successful.

Lastly, in addition to the importance of governance innovation for firms lacking financial resources, we believe this is applicable to firms experiencing technological gaps. In our study, although Hynix arguably had a strong foothold in DRAM technology prior to its turnaround, it was a latecomer to NAND flash and was hindered by a lack of financial resources in pursuing the business aggressively by itself. Management transformed these difficulties into opportunities by seeking new ways of approaching the market via overseas technological alliances. We believe governance innovation allowed for and encouraged such innovation to take place. As a result, we propose the following:

Proposition 3: The lower the technological resources a firm possesses, the more important the role of governance innovation in making the firm successful.

\section{UNFOLDING LITERATURE}

The concept of governance innovation was developed as an extension to the broader idea of management innovation. In the research of Birkinshaw et al. (2008), management innovation refers to the invention and implementation of a management practice, process, structure, or technique that is new to the state of the art and is intended to further organizational goals. In illustrating how manage- 
ment innovation comes about, analysis is focused on key change agents inside and outside the organization in driving and shaping four processes-motivation, inventtion, implementation, and theorization and labeling. Of these processes, our research focused on the innovation process as it relates to decision-making. While this process refers to the phase in which a hypothetical new practice is first tried out in an experimental way, our findings led us to suggest a broadening of "new practices" to encompass control systems by which decisions are made in the firm (i.e., governance innovation). We highlight governance innovation as an extension of management innovation within a list of key examples provided by Birkinshaw et al. (2008) in Figure 4.

\section{FigURE 4. EXAMPLES OF MANAGEMENT INNOVATION}

\begin{tabular}{|c|c|}
\hline Example & How if fits the definition of management innovation \\
\hline Modern research lab & $\begin{array}{l}\text { A new structure to manage the technological innovation process; } \\
\text { intended to improve technological and product innovations }\end{array}$ \\
\hline Divisional (M-)form & $\begin{array}{l}\text { A new organizational structure for dealing with complex, } \\
\text { multiple-product, and multiple-market firms }\end{array}$ \\
\hline Toyota production system & $\begin{array}{l}\text { A new set of practices and processes aimed at improving } \\
\text { production efficiency and reducing waste }\end{array}$ \\
\hline Total quality management & $\begin{array}{l}\text { A new set of practices and processes aimed at reducing quality } \\
\text { defects and improving customer satisfaction }\end{array}$ \\
\hline Discounted cash flow & $\begin{array}{l}\text { A new technique intended to improve investment and budgeting } \\
\text { decisions by adding a temporal dimension }\end{array}$ \\
\hline Spaghetti organization & $\begin{array}{l}\text { A new organizational structure with the objective of increasing } \\
\text { employee initiatives and overcoming problems of hierarchy }\end{array}$ \\
\hline Cellular manufacturing & $\begin{array}{l}\text { A new process for managing tasks inside a production unit } \\
\text { aimed at improving employee satisfaction and production output }\end{array}$ \\
\hline NASA new organization & $\begin{array}{l}\text { A new structure and practice for teams to perform complex } \\
\text { modeling and analysis without colocation }\end{array}$ \\
\hline Activity-based costing & $\begin{array}{l}\text { A new practice and technique for assigning costs aimed at } \\
\text { providing more realistic cost assessments }\end{array}$ \\
\hline Modern assembly line & $\begin{array}{l}\text { A new set of practices and processes with the goal of improving } \\
\text { production efficiency and lowering costs }\end{array}$ \\
\hline Balanced scorecard & $\begin{array}{l}\text { A new technique and practice for integrating various types of } \\
\text { information with the aim of making more informed decisions }\end{array}$ \\
\hline Quality of work life & $\begin{array}{l}\text { A new set of practices and processes around the job design of } \\
\text { employees with the goal of improving their happiness at work }\end{array}$ \\
\hline Governance innovation ${ }^{*}$ & $\begin{array}{l}\text { A new structure that generates and cultivates innovation in the organization's } \\
\text { control mechanisms with the goal of fostering innovative processes }\end{array}$ \\
\hline
\end{tabular}

SOURCE: Birkinshaw et al. (2008).

NOTE: ${ }^{*}$ denotes this paper's contribution to the existing research.

In conceptualizing governance innovation, we do not ignore the role of strategic innovation, technological innovation, and other important initiatives that contributed to the firm's success. Rather, we view that high innovative capabilities regarding control and governance mechanisms enabled agents within the firm to 
implement other forms of innovation more effectively. In this sense, we found that governance innovation served as a type of dynamic capability that in turn contributed to the firm's outperformance. Research on dynamic capabilities by Teece (1994) explain how competitive advantage is gained and held by firms, and argue that winners have demonstrated timely responsiveness and rapid and flexible product innovation, along with the management capability to effectively coordinate and redeploy internal and external competences. Subsequent research by Teece et al. (1997) and by Eisenhardt and Martin (2000) also characterize dynamic capabilities as having emerged from path-dependent histories of individual firms. But through our investigation, we view that governance innovation was low or nonexistent during the M\&A and crisis phases of Hynix's history and question the direct applicability of this general characterization for our analysis. We believe that strategic and technological innovations that took place at the firm were more sudden phenomena which resulted from a higher degree of governance innovation at the early stages of its turnaround. But rather than discrediting the generally path-dependent nature of the development of dynamic capabilities, we take the view that governance innovation was a form of latent dynamic capability triggered in large part due to a crisis mentality following the firm's near-collapse.

As follows, our study encouraged us to examine the question of how firms can initiate or increase the level of governance innovation for the purpose of enhancing performance. For one, academic literature points to the possible role of poor performance in a firm leading to organizational change because good performance may lead to inertia (Boeker 1997; Hannan and Freeman 1984; Nelson and Winter 1982; Oster 1982). Following our data collection and analysis, we believe this view is consistent with Hynix following its crisis years as poor performance and an ensuing crisis mentality served as catalysts to innovation. And while our study may prove more useful to firms facing financial and technological gaps versus peers, we note that existing literature, and to some extent our investigation, is less explicit on initiatives that can be taken by firms that are facing relatively fewer external or internal difficulties in order to enhance performance.

\section{CONCLUDING REMARKS}

While acknowledging the role of uncontrollable external factors such as an industry upturn and favorable foreign exchange in contributing to Hynix's turnaround, we believe these reasons are insufficient explanations in and of themselves. This is because while they can explain Hynix's survival, they have less explanatory power regarding the firm's outperformance versus peers-specifically as the firm faced financial and technological gaps. Thus in our investigation, we pinpointed governance innovation as the key internal catalyst that led to Hynix's turnaround as it opened the door for other forms of innovation to take place. 
One key limitation of this research is the measurement of the degree (or existence) of governance innovation in firms using qualitative evidence. But while this can provide a relative comparison between distinct time periods within a particular firm, future research may focus on developing a set of criteria that can better objectively and quantitatively measure the level of governance innovation at any firm. This would be particularly useful in comparative analyses.

Additional avenues for future research include in-depth comparative studies between Hynix and relevant players in the memory industry. While our study provided a first blush, deeper intra-industry analysis of respective firms' control systems and management strategy may enhance the findings of this paper. In addition, as one of our key research goals includes providing a practical framework for other firms to replicate Hynix's success, further research can be undertaken to test the framework's applicability to industries other than the high-tech industry.

\section{REFERENCES}

Birkinshaw, J., Hamel, G.., and Mol, M. 2008. Management Innovation. Academy of Management Review 33(4): 825-845.

Boeker, W. 1997. Strategic Change: The Influence of Managerial Characteristics and Organizational Growth. Academy of Management Journal 40(1): 152170 .

Brandenburger, A., and Nalebuff, B. 1997. Co-Opetition. Broadway Business: New York.

Bridges, B. 2001. Korea After the Crash: The Politics of Economic Recovery. Routledge: London, U.K.

Burton, R., DeSanctis, G., and Obel, B. 2006. Organizational Design: A Step-ByStep Approach. Cambridge University Press: Cambridge, U.K.

Cooper, A. and Bruno, A. 1977. Success Among High-Technology Firms. Business Horizons April 1977: 16-22.

Eisenhardt, K. 1989. Building Theories from Case Study Research. Academy of Management Review 14(4): 532-550.

Eisenhardt, K. and Martin, J. 2000. Dynamic Capabilities: What are They? Strategic Management Journal 21:1105-1121.

Eisenhardt, K., and Schoonhoven, C. 1990. Organizational Growth: Linking Founding Team, Strategy, Environment, and Growth Among US Semiconductor Ventures, 1978-1988. Administrative Science Quarterly 35(3): 504-529.

Feeser, H. and Willard, G. 1989. Founding Strategy and Performance: A Comparison of High and Low Growth High Tech Firms. Strategic Management Journal 11(2): 87-98.

Haleblian, J. and Finkelstein, S. 1993. Top Management Team Size, CEO Domi- 
nance, and Firm Performance: The Moderating Roles of Environmental Turbulence and Discretion. Academy of Management Journal 36(4): 844-863. Hamel, G. 2006. The Why, What, and How of Management Innovation. Harvard Business Review 84 (2): 72-84.

Hannan, M., and Freeman, J. 1984. Structural Inertia and Organizational Change. American Sociological Review 49(2): 149-164.

Helfat, C., Finkelstein, S., Mitchell, W., Peteraf, M., Singh, H., Teece, D., and Winter, S. 2007. Dynamic Capabilities: Understanding Strategic Change in Organizations. Blackwell: Oxford, U.K.

Irwin, D. 1996. Trade Politics and the Semiconductor Industry. In The Political Economy of America Trade Policy, Krueger, A. (ed). The University of Chicago Press: Chicago.

Jun, H., Woo, W., and H. Kang. 2013. Hynix Semiconductor: Global Pioneer. Asian Case Research Journal 17(1): 145-160.

Nelson, R., and Winter, S. 1982. An Evolutionary Theory of Economic Change. Belknap Press: Cambridge, MA.

Oster, S. 1982. Intraindustry Structure and the Ease of Strategic Change. The Review of Economics and Statistics 64(3): 376-383.

Pettigrew, A. 1990. Longitudinal Field Research on Change: Theory and Practice. Organization Science 1(3): 267-292.

Roberts, E. 1992. The Success of High-Technology Firms: Early Technological and Marketing Influences. Interfaces 22(4): 3-12.

Roure, J. and Keeley, R. 1990. Predictors of Success in New Technology Based Ventures. Journal of Business Venturing 5(4): 201-220.

Roure, J. and Maidique, M. 1986. Linking Prefunding Factors and High-Technology Venture Success: An Exploratory Study. Journal of Business Venturing 1(3): 295-306.

Teece, D. and Pisano, G. 1994. The Dynamic Capabilities of Firms: An Introduction. Oxford University Press: Oxford, U. K. 